\title{
Ssciendo
}

Ethics \& Bioethics (in Central Europe), 2020, 10 (3-4), 179-189

DOI:10.2478/ebce-2020-0016

\section{Cultivated character: Voltaire and Karel Čapek on the good gardener}

\author{
Daniel Brennan ${ }^{1}$
}

\begin{abstract}
The paper unpacks the nuanced ethical potential in the metaphor of gardening that is depicted in Karel Čapek's The Gardener's Year, and the relevance of Čapek's metaphor for understanding Voltaire's famously ambiguous ending to Candide. Against more pessimistic or passive accounts of what Candide could have meant, the paper agrees with scholars who consider Candide's maxim as meaning to engage in active, and communal practise of character development. By using Čapek's much fuller account of the gardener in the practice of cultivation to fill in the gaps in Voltaire's account, the paper shows that gardening is a rich metaphor of the virtuous person engaged in lifelong character cultivation.
\end{abstract}

Keywords: Karel Čapek, Voltaire, Gardening, virtue ethics, humanism

Karel Čapek's The Gardener's Year (Zahradníkův rok), published in 1929 is ostensibly a lighthearted book on the joys and frustrations of gardening. ${ }^{2}$ Presented as a quasi-guide to gardening practice, the book explores the aspirations and behaviors, for a generalized gardener over the course of a year. Although treating a fairly mundane topic, The Gardener's Year fits in quite well with Čapek's oeuvre, as it offers an insightful interpretation of ordinary life, that is brimful of his liberal, humanist position. The book is replete with implied philosophy that belies its mundane topic. Gardening operates for Čapek as a metaphor for the human endeavor. In much of his journalism, Čapek offered vignettes of ordinary life, in which he propounds humanist values. He also critiques decadent human practices which could be renewed through humanist action.

Similarly, in many of his plays and novels, overly confident and modern individuals and societies are brought undone through their hubristic attempts to control nature. In The Gardener's Year, Čapek depicts the gardener as a person embedded in nature, and in culture, who never conquers, nor has total control over either sphere of activity, and also finds a harmonious way to live with others in a manner which brings much beauty to the world. Hence the gardener is a rich metaphor for Čapek's view of the virtuous person.

The book has received scant attention in English language scholarship. Indeed, the very metaphor of gardening is also under-represented in philosophical discourse of the human condition and societal renewal. In this paper, I will explore Čapek's use of gardening as a metaphor and make a case for its philosophical richness. Furthermore, I will show that Čapek's specific depiction of the gardener is one of the richest uses of the metaphor in western literature.

In the canon of western literature, apart from philosophy, there is a long history of gardening being employed as a metaphor for considering the human condition. It is interesting that in western philosophy there is very little on gardening and philosophy. In one of the very few philosophical treatments of philosophy and gardening, David Cooper remarks that if we are to look for a philosophy of gardens then we might need to reconsider what a philosopher is. Cooper looks to figures like Virgil, Herman Hesse, or, as I do here, Karel Čapek (Cooper, 2006, p. 3). For Cooper these authors were all philosophically trained and their philosophical positions informed their literary endeavors. Hence, there is good reason to hope for finding philosophical insight into gardening through a study of certain literature.

\footnotetext{
${ }^{1}$ Bond University, Gold Coast (Australia); dbrennan@bond.edu.au

${ }^{2}$ For the entirety of this paper, including all quotations, the 1931 translation of the text by M. \& R. Weatherall has been used (Čapek, 1984).
} 
Anders Cullhed, in a sweeping analysis of the use of the gardening metaphor in Western literature, describes its lineage from the garden of Eden in the Book of Genesis, through Jean de Meun's The Romance of the Rose, and through to Voltaire's famous parting advice in Candide (Cullhed, 2010, p. 6). He argues that the garden is mostly viewed as a site of blissful eroticism - an escape from the pains of the world. The garden, for Cullhed stands as a "utopian dream for suffering mankind" (Cullhed, 2010, p. 6). However, Cullhed points out that this dream is open to multiple interpretations. In Eden, man's expulsion from the garden means that we must toil in pain to survive. By the time Voltaire has Candide declare that "we must cultivate our garden", Cullhed suggests the toil, so clearly a negative in Genesis, is now a positive means of salvation, associated with useful activity and not merely pain (Cullhed, 2010, p. 7). To further confuse the meaning of the metaphor, interpreters of Voltaire are not in agreement about what the cultivation of our gardens actually entails. Candide does not elaborate in the novella, and neither does Voltaire in other works.

\section{Voltaire and Candide, the cultivation of one's garden}

Hence for some critics, Voltaire intended through his gardening metaphor to encourage people to escape from the horrors and evils of the world to a privately owned space of personal toil in which to find brief moments of repose. Philip Stewart for example, contends that the garden is a refuge (Stewart, 2009, p. 135). Similarly, Salman Rushdie, in a journalism piece for The Guardian, contends that "Voltaire's great fable ends with the suggestion that in appalling times we would be well advised to keep our minds off high ideas and our noses out of great affairs, and simply cultivate our gardens" (Rushdie, 2002). The garden is thus a symbol of an escape to the quiet life - the blissful eroticism of Cullhed's account - a bracketing off, or hiding from the world's ill for private pleasure.

Roy Wolper, building on those who suggested that Candide, and by extension Voltaire, is arguing for a retreat from worldly matters, suggests that Candide is a mere character who was never intended by the author to have learned anything (Crocker \& Wolper, 1971, p. 150). For Wolper, Candide wants a small plot for himself to cultivate because it is nicer than anything else he has experienced (Crocker \& Wolper, 1971, p. 148). For Wolper, Candide is unaware that the gardener could have his plot destroyed by radical evil as it marches around the world haphazardly (Crocker \& Wolper, 1971, p. 148). Candide, the gardener, is hence not only an escapist who refuses to consider his duties to others; he is also naïve in that he has not learned the lessons of his experience (that bad things happen randomly and with little ability to defend against them).

Candide's maxim has also been read as an explanation of the absurd (Crocker \& Wolper, 1971, p. 148). If the world that Candide has experienced, full of inexplicable evil, is as things really are, then it clearly has no rational basis. Gardening is thus a response to the absurd. Wolper moves slightly away from this position suggesting that the work of cultivation is a remedy to the ills of the world only for the gardener (Crocker \& Wolper, 1971, p. 149). That is, it makes no difference to the world as such, but to their private worlds there is some temporary ease. I have difficulty with this interpretation as it seems to set the metaphor up in a false dilemma. Either a garden solves the world's problems totally, or it is a private affair. I would perhaps agree that as a total response to evil, the cultivation of one's garden could not be a complete panacea. I would add that not much can. However, this does not preclude the possibility of gardening being a part of the treatment. That is, it does not follow the world is necessarily absurd in the sense that Wolper means absurd (totally lacking in rationality) if gardening is the means of renewal. One might suggest that better education is a part of the response to a decadent world. One would be mistaken to then say that because those who become educated do not go on to fix all of the world's problems that education is therefore 
unimportant. Rather, and this is much clearer in the next interpretation of Candide's maxim, the cultivation of a more educated community produces a community of (hopefully) critical thinkers who make more morally sound decisions - it is hence a case for meliorism, not revolution.

The final interpretation of Candide's maxim reflects this meliorism. For some critics gardening as Candide describes it, represents the idea that we are to strive for a better world here, in this world, as it is given to us - in full knowledge that not every attempt will be successful. Such is the view of Ari Hirvonen who offers a three-level interpretation of Voltaire's garden cultivation metaphor (2014). Firstly, the maxim of Candide is an imperative to progress (Hirvonen, 2014, p. 232). Perhaps pruning the oppressive qualities of society, and watering those with just blossoms. Secondly, for Hirvonen, Voltaire's garden is a space of resistance and revolt (Hirvonen, 2014, p. 233). Hirvonen writes that "the garden is a space of tolerance that challenges all kinds of miscarriages of justice." Finally, the cultivation of a garden is the making possible of a community (Hirvonen, 2014, pp. 233-234).

To be in the garden is to be with others. However, this being-together, which is not grounded on any onto-theological god or transcendental being, is a limited existence. As Candide and his friends cultivate the garden, they are exposed to limits that are not at their disposal: flowering and death. Thus, Voltaire's garden is about our existing as finite beings in a world that is never our own (Hirvonen, 2014, pp. 233-234).

What this interpretation offers is an imagining of the garden and its fecundity, as a symbol for social renewal. More than that, it is a non-violent, non-militaristic account of resisting oppression. It is also a plea for a humble account of man's place in nature. The collective enterprise of gardening is also highlighted by David Williams in his book-length study of Candide. For Williams, the pursuit of happiness, in Candide's formulation, is only possible in terms of cooperative endeavors (Williams, 1997, p. 90).

These more optimistic interpretations of gardening in Candide, stress not only the cooperative element of the activity but also the finiteness of the task amongst the infinite stretch of nature (in terms of magnitude and time) - that is they consider the gardener as a metaphor for man's being in the world. The garden of Candide's maxim is not a remaking of Eden as an alternative to rationality, but "a world of action, solidarity and collective human endeavor and aspiration" (Williams, 1997, p. 91). Such action is not aimed at utopia, but rather recognizes the lack of guarantee for fortune. We should garden because it is the most ethical thing to do in the face of a world where bad things happen. We must cultivate our communities and attempt to satisfy our human needs because to do so is the best way to participate in a world in which good things happen but are not guaranteed. The striving of the gardener is thus an excellent metaphor for the virtuous human being. The person who tends to the world around them so that beauty has a chance to emerge. Furthermore, the gardener is a part of a community of gardeners, holistically improving the places in which they dwell.

\section{Čapek's gardener; Filling in the row}

Of course, this is a lot to make out of what is really a single sentence (albeit it with some literary context around it) uttered by a character who for many critics is not the mouthpiece of Voltaire. Hence, it is to the characteristics of gardening itself that better elucidation of the metaphorical potential of the activity can be found. If gardening is a solitary, lonely escapist pursuit then the reading of Candide as an escapist is correct. If gardening offers absolution only for those who engage in it then Candide is as Wolper suggests naïve to his experience and looking for brief reprieve from evil. However, if gardening is the kind of epistemically humble and cooperative activity defined in the final interpretation, then Candide is offering a maxim of hope and 
possibility. It is necessary to look beyond Voltaire's book as he writes too little on the metaphor, thus inviting ambiguity and hence making it difficult to find the dominant interpretation.

It is in Capek's book that such an elucidation takes place. Čapek has the space of an entire monograph, that describes a full year's activity within which to describe the characteristic activity of the gardener. The book also hints at extended time, as the gardening year leads into the continuing cycles of nature (the year described could be any year, and indeed the book's popularity some 90 years after initially being published is testament to the timelessness of the vignettes). Hence there should seemingly be little chance of confusing the metaphor. However, the way that the English translations of the book (and there have been multiple translations and many editions), are advertised and reviewed, reflects the same diverse ways that gardening as a metaphor in Candide has been interpreted. For example, in the explanatory blurb on the publisher Bloomsbury's website for Geoffrey Newsome's translation, the book is described in the marketing as something that "will be treasured equally by those who love gardening as relaxation, by those who loathe it as a chore, and by those who have no interest in it whatsoever." Gardening is clearly interpreted as an escapist pursuit, undertaken primarily for relaxation and that any disagreement about the characteristics of the activity would be about whether it is fun or not. There is good reason to reject this interpretation, as I will demonstrate through the remainder of this paper the philosophical, and literary richness of the text.

On the other hand, the publisher Random House, released a translation as a part of the Modern Library Gardening series. The series editor, Michael Pollan, himself a famed 'gardening' writer, is also a serious activist, producing much-lauded journalism on the problems of industrial farm practices, and the social and political importance of recovering small scale food production. For Pollan, the choice to include a translation of Čapek's book in the series is because of the attention on the gardener's themselves, rather than instructions on how to garden (Hill, 2009). The perspective of the book is insightful, as Čapek is more focused on the person of the gardener and their virtues. That is, the book is depicted as a description of the actions of the gardener, not a recounting of an escapist hobby. As I will develop below, the virtues are ethical rather than merely related to the activity of gardening itself. What is practised in gardening, for Čapek has importance for the world, and not merely a closed off and private part of it. As Cooper writes, what Pollan and Čapek can agree on is the richness of the idea that the gardener communes with nature (Cooper, 2006, p. 74). That is, what could be, in baser gardening journalism, a cliched and hence empty statement, in writers like Pollan is a robust account of how gardening brings humanity in closer relationship to the world they live they inhabit.

Even in scholarship, apart from the all to brief mentions of Čapek's work in Cooper's book, there seems to be a lack of nuanced reading of Čapek's text. In reviewing a translation of The Gardener's Year in the Slavic and East European Journal, Craig Cravens fits the book to Čapek's critique of modernity (2007). Cravens rushes to describe the themes of R.U.R. and War With the Newts to then argue that The Gardener's Year is a book about individuals hubristically trying to overcome and control nature.

Through a discussion of gardening, Čapek treats the human condition - mankind's arrogant attempts to tame, domesticate, and overcome nature. With Čapek, however, the ruminations are not nearly as overwrought as the previous sentence suggests. He characteristically arrays his philosophical insights in deceptively light and airy garb to create a collection of essays that appeals to all manner of readership save those who seek more melodramatic philosophy (Cravens, 2007, p. 176).

Cravens also adds to his suggestion that the book is light on ideas by contending that "Čapek's sententiae are few and far between". What Cravens is apparently looking for is explicit philosophical articulation. However, I contend it is already there, contained within the richness 
of the metaphor of the gardener. I agree with Pollan, Čapek's little book is really about our human all too human endeavors, in fact, Capek even writes that a garden is "like the human world and all human undertakings" (Čapek, 1984, p. 132). If we take Čapek at his word, then all of the activities of the gardener are about all humans. Every passage of the book is thus brimful of moral significance, rather than such moral sayings being "few and far between" as Cravens reads it (Cravens, 2007, p. 176). There is good reason to think this as Čapek scholarship usually contends that Čapek wrote with the same humanist motives across all of his writing. Haman and Trensky contend that Čapek is constantly preoccupied with the same weighing and judging of the world through his humanist, pragmatic attitude to life (Haman \& Trensky, 1967, p. 175).

Furthermore, as they read Čapek, even in his journalism, and smaller pieces, Čapek expresses a keen desire to effect a moral influence on the world (Haman \& Trensky, 1967, p. 175). Hence, no matter the subject of his work, whether that be an epic account of humanity in a novel, or a small vignette for a newspaper, or indeed a small book about gardening, Čapek's writing is built around his personal morality. Haman and Trensky ultimately contend that the key to understing Čapek's writing is to see it as the construction of a literary world into which the epic human struggle for morality and meaning can play out. They also contend that Čapek "projected his historical utopia of the brotherhood for all" into the "theatrum mundi" created in his texts (Haman \& Trensky, 1967, p. 183). That the book on gardening could be such a theatrical, and epic world where a vision of a moral world can be weighed and judged, in my view, immediately connects the work to Candide. Furthermore, I will argue that The Gardener's Year is a more robust description of Candide's maxim when that maxim is interpreted as an ethical activity of communal worldly renewal.

Cravens is partly correct that the book treats the arrogance of humanity's attempts to control nature. Such critique is a recurrent and vital theme in Capek's oeuvre. In War With the Newts, Capek depicts the destruction of the world and people through the operations of perverse rationality. Similarly, in R.U.R., the development of thinking robots leads to the destruction of all humans. In Čapek's work, there is a very strong critique of the totalizing politics of fascism and scientism, which seek to see the world through one lens. However, Čapek is also a staunch humanist. The tendency of some parts of human culture to search for totalizing answers to politics and nature is tempered by the humanist potential to celebrate the diversity of the human experience, and also to be humble in our inability to control nature. That is to say that the satirical element of Capek's writing is not merely a critique of delusions of titanism; but rather, as Haman and Trensky explain, Capek's satire "is built upon a practical, personal morality" (Haman \& Trensky, 1967, p. 175). Contained within the satirical critique, is also the presentation of the solution. Capek's gardener is hence not only foiled by the inadequacy of technology but also able to work within those constraints to produce a beautiful garden.

Consider the humorous description of a garden hose in The Gardener's Year. For Cravens, it is a part of the critique of an overly zealous faith in technology to improve life. However, when viewed in its full context, the gardener's struggle with the hose is representative of humanist attempts at progress and a humble orientation to the seemingly Sisyphean task.

It will soon be clear that until it has been tamed a hose is an extraordinarily evasive and dangerous beast, for it contorts itself, it jumps it wriggles, it makes puddles of water, and dives with delight into the mess it has made; then it goes for the man who is going to use it and coils itself around its legs... You must grasp it firmly and hold it tight; the best rears with pain and begins to spout water, not from the mouth, but from the hydrant and from somewhere in the middle of its body. Three men at least are needed to tame it at first, and they leave the place of battle splashed to the ears with mud and drenched with water; as to the garden itself, in parts it has changed into greasy pools, while in 
other places it is cracking with thirst. If you do this every day, in a fortnight weeds will spring up instead of grass (Čapek, 1984, p. 8).

Humorous, and seemingly light, the above passage is more than mere critique. There is no underlying message that one should not use a hose. Even the eventual growing of weeds is not a reason to not plant seeds, but an imperative to strive more as the next passage is on the endlessly necessary task of weeding (something like the activity of a happy Sisyphus). The snake-like hose is not the creature keeping us from Eden, nor is it poisonous, and a part of the slope towards decadence and oblivion. Instead of being a mere light-hearted anecdote, Čapek's hose is a flawed, but not entirely ineffective piece of human ingenuity which will not tame, nor control nature, but will eventually, perhaps, produce beauty. It is also an activity requiring a community of gardeners as many are required to hold it. As further support of the optimistic content of the hose motif consider the next time the hose appears. The second appearance of the hose is not comic, it is instead described as a part of a sacred encounter between gardener and land.

But there is one moment when the gardener rises and straightens himself up to his full height; this is in the afternoon, when he administers the sacrament of water to his little garden. Then he stands, straight and almost noble, directing the jet of water from the mouth of the hydrant; the water rushes in a silver and kissing shower; out of the puffy soil wafts a perfumed breath of moisture, every little leaf is almost wildly green, and sparkles with an appetizing joy, so that a man may eat it (Čapek, 1984, p. 39).

The gardener is doing something sacred, not merely mundane. It is important that the gardener is "almost noble", and the leaf is almost "wildly green". These adjectives are explicitly limited by Čapek. Instead of the comedy of the cobra-like hose, this time Čapek is careful to repeat the lesson but in a different tone. The gardener is close to nobility; however, they are not imbibed with hubris. The garden is close to wild nature, but not it entirely either. The garden and the gardener are also, importantly, not lesser, nor profane; instead, they are just not perfect. In Capek's description, the desire to garden and the use of tools to attempt it are not a part of man's hamartia, nor is it a sign of our divinity. Instead for Čapek, they are means of mixing the sacred with the mundane.

Rather than being anti-technology, or human advancement, Čapek presents the gardener as an exemplar of the virtuous person. A measured, epistemically humble, community-minded, and patient individual who finds the good life through their practice. By focusing on the character traits of the gardener Čapek adds another ethical dimension to the metaphor of the gardener. The gardener's qualities are more than accidental attainments or passionate outburst. They are practised, beneficent, psychological traits that present as an orientation of care towards the world and its inhabitants. Matthew Dinan, in writing about R.U.R., argues that for Čapek, "loving attentiveness to the preservation of humanizing conditions is the counterintuitive basis of all real "progress"" (Dinan, 2017, p. 109). The same insight is easily applied to The Gardener's Year.

\section{The virtues of Čapek's gardener}

There is also a strong connection between the gardener's striving and good fortune that is well worth elaborating. The role of luck in the production of a beautiful garden is reminiscent of the role of luck and fortune in Aristotle's Nicomachean Ethics (1976). For Aristotle, the virtues are a necessary but not sufficient component of the good life. What an agent requires, is also the luck that their efforts come to fruition. Aristotle's views on luck and the virtues are well explained by Sarah Broadie in her paper 'Aristotle on Luck, Happiness, and Solon's Dictum' 
A passage of virtuous activity directed at making a difference in the world can be frustrated by bad luck; hence it depends for success on the lucky absence of bad luck. But the virtuous activity itself (the "trying"), as distinct from the intended result, wholly depends on the agent and so is invulnerable to luck (Broadie, 2019, p. 31).

The above is insightful for understanding Čapek's gardener, and the metaphor of gardening, as it is important to consider how the gardener is depicted as they stand surrounded by thwarted efforts at coaxing flowers from the soil. It is clear that luck plays a major role, and it is also clear that the gardener does not have access to a superrational principal of gardening, like, for example, a categorical imperative, to guide their actions. Rather they are a person who tries, or strives, and develops habits. Clearly, this is not an activity in an absurd world, as one of the above-explained interpretations of Candide's maxim has it; instead, the virtues are a rational response to the lack of ability to predict the capriciousness of nature, weather, neighbors or whatever else could cause seeds to not sprout. The point is not the beautiful garden is guaranteed, it requires a confluence of elements which all depend to an extent on luck; but also, without the striving of the gardener, there is no garden either. Hence, like Aristotle's virtues, the practice of enthusiastic gardening is necessary for the good life, even though that happiness could be thwarted.

Consider the following passage humorously describing the gardener attempting to till the frozen soil of a Czechoslovakian January.

And look, the thaw is here, and the gardener rushes into the garden to till the soil. After a while he brings home, stuck to his boots, all that has thawed on the surface; nevertheless he looks happy and declares that the earth is opening already. In the meantime nothing is left but "to do some work ready for the coming season" (Čapek, 1984, p. 20).

It is impossible to read gardening in Čapek's description, as being relaxing, or even something to be undertaken as a past-time. It is too involving for that, requiring year-round attention and constant struggle. The gardener, Čapek writes, "is not a man who smells a rose, but who is persecuted by the idea that "the soil would like some lime" (Čapek, 1984, p. 37). Yet for all of the continued effort they are rewarded, despite the possibility of failure, with a wondrous experience of nature that speaks of more than human consciousness can make sense of. Consider the above passage of the gardener administering the sacrament of water to their garden. The reward for toiling with the cobra-like hose is the witnessing of nature's advancement. For Čapek "a gardener's pleasure is deeper rooted, right in the womb of the soil" (Čapek, 1984, p. 37).

The gardener, if patient, is also rewarded with a knowledge of nature, not a totalizing, Baconian knowledge that allows control, but rather one that allows coexistence. Čapek's gardener understands the phrases, "the bitter cold" or "the merciless north wind", and waits, patiently attuned to weather forecasts on the radio for moments of reprieve from violent weather so that restorative work can be done (Čapek, 1984, p. 39). The knowledge that allows the capriciousness of nature to be endured is also found in the communal aspect of gardening. Capek writes that the gardener goes out of their way to meet older gardeners who possess memories of worse weather patterns so that they can, in solidarity recognize their powerless against nature, but also the potential to regroup in more favorable conditions. Again, this is clearly not a description of an absurd and contingent evil, but rather a refocusing of the place of man in nature, and the establishment of a community, who through shared knowledge and toil encourage progress in their love of the human, all too human condition. Consider the following vignette: 
I will not betray to you how gardeners recognize one another, whether by smell, or some password, or secret sign; but it is a fact that they recognize one another at first sight, whether in gangways of the theatre, or in a dentists waiting room; in the first phrases which they utter they exchange views on the weather ("No, sr, I never remember such a spring"), then they pass to the question of humidity, to dahlias, artificial manures, to a Dutch lily ("damned thing; what's its name, well never mind, I will give you a bulb"), to strawberries, American catalogues, damage from last winter, to aphis, asters, and other such themes. It is only an illusion that they are two men in dress suits in the gangway of the theatre; in deeper and actual reality they are two gardeners with a spade and watering can (Čapek, 1984, pp. 45-46).

The gardeners are immersed in society and culture, and also in their gardens. Their gardening is not private but shared in social spaces. They are generous to each other and communicate what knowledge, and lack of experience they have, so that each may improve their garden. It is a powerful statement that despite their dress, and immersion in cultural institutions like the theatre, there is a more real identity as a gardener, and for Čapek that identity is inherently social.

Earlier in the book Čapek declares that a real gardener is someone who says that "you must come to see me... I will show you my garden" (Čapek, 1984, p. 12). The showing of the garden is not only for pride or showing off, but a sharing of ideas, and plants - it is, as in my preferred interpretation of Candide, a communal affair that is a valid response to a world that can be malicious. The gardener is also an exemplar to other gardeners. In a striking passage about neighbors, Čapek contends that one can tell when the Spring has come by the appearance of neighbors in their gardens. Once one has that sight or sense, one is then duty-bound to don gardening clothes and tools and head out as well, to be the virtuous example to other neighbors.

Along with this knowledge and community, there is the requirement of patience. Gardening is an activity of waiting. Of letting nature's courses run, and intervening as far as possible and appropriate, with a moderated hand. As Čapek writes, "[a]nd then one must wait and wait!... And then in the meantime, without the gardener having suspected, nor having done anything crocuses and snowdrops has pricked through the soil" (Čapek, 1984, p. 22). Of course, the gardener has "done" something. The gardener has been, all year long, tending the soil, weeding, preparing, and waiting. In the instant of the flower appearing it may look like no effort has gone into it, but as Čapek recounts, there is so much effort around the sprouting, that enabled the sprouting to be possible. So that the striving effort of the gardener compliment the contingency of nature a certain epistemic humility is necessary. Such an epistemic standpoint is in my reading, similar to the virtue of mesure described by Albert Camus.

Mesure, as a Camusian virtue is a kind of practised moderation. Matthew Sharpe describes mesure as:

\begin{abstract}
'balance' or 'moderation.' This position recognizes the importance of, and tries to comprehensively balance both sides of the oppositions that Western thought has lurched uneasily between, excluding no evidently salient dimension of our shared condition: nature-history; reason-affect; justice-love; political duty-happiness; individualcollective; exile-kingdom; sacred-profane; contemplation-action; withdrawalengagement; innocence-guilt; assent-negation or revolt; unity-difference (Sharpe, 2015, p. 26).
\end{abstract}

For Sharpe, mesure is a philosophical position of recognizing the limits of human comprehension of our activity. However, this is not to say that mesure knows of nothing; instead, it is a recognition that totalizing answers exclude that which they are in opposition. For Sharpe, mesure is a virtuous outlook because it is more than an emotional reaction to an unknowable world. It is a practised moderation of the passionate attempt to know or control 
everything (Sharpe, 2015, p. 26). Mesure is hence like the gardener's humility in that the gardener's basic epistemic orientation is to acknowledge that nature cannot be controlled and that a garden is possible within that nature. What the gardener receives for that orientation is not more knowledge, but the experience of wonder. An insightful account of planting a seed in a pot demonstrates the combined activity of mesure and the experience of wonder.

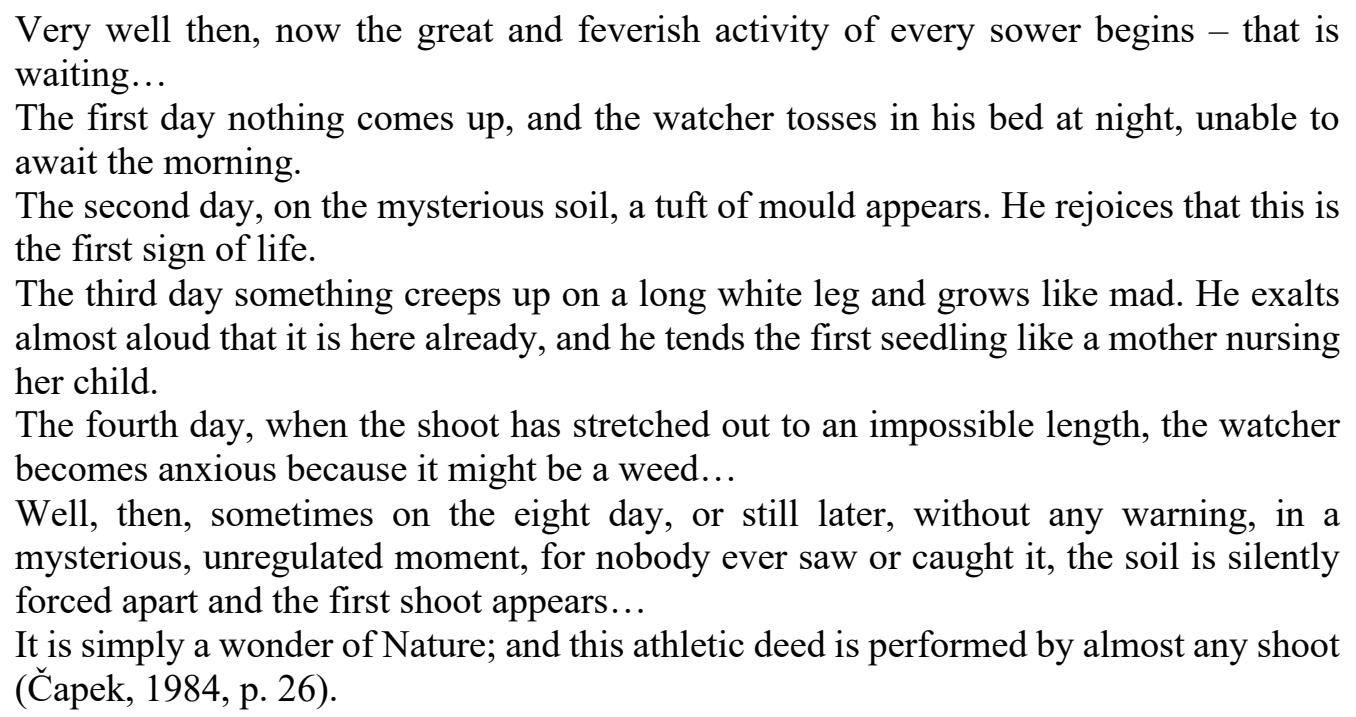

The section concludes with Čapek wondering, "What did I want to say? Oh, I know - nothing; only that life is more complicated than one can imagine" (Čapek, 1984, p. 26).

The effect of this wonder on the character of the gardener, is to direct the gardener's concern towards a better future. In this lies the crux of my argument that the gardeners of Čapek, (and Voltaire) are a valid response to a world where bad things can happen to good people. The gardener is not retreating to a private place of contemplation, where some other workers have done the hard work of producing the garden; they are the future-orientated workers cultivating progress. The sense that the gardener cares for the future goes further than saying the gardener awaits the blooms of the seeds they sow. For Čapek man is placed in the somewhat eternal cycles of nature, and it is to longer than the flowering of one plant that the gardener directs care. Each year brings new challenges, but the growing of a garden, and being a good gardener are life-time pursuits. It is in the repeated motif of soil improvement that the strongest sense that the care for the future well-being of the garden is an allegory for ethical concern for progress can be found. The plants themselves are, for Čapek, almost incidental to the nurturing of the soil in which such beautiful things can grow. The tending of the soil is hence the strongest metaphor for being orientated to the world with care because it does not seek to control what grows, only the potential that growth can occur. For Čapek, "the real gardener is not a man who cultivates flowers; he is a man who cultivates the soil" (Čapek, 1984, p. 34). Humorously, Capek declares that the gardener, if allowed back into Eden, would ignore the flowers and fruits and immediately wax lyrical on the qualities of the humus (Čapek, 1984, p. 34). They are thus workers for progress, not contemplators in retreat.

That the activity of the gardener reaches beyond the immediate present suggests that gardening is a philosophy as a way of life. I would say that Čapek's view is somewhat reminiscent of a more classical form of conceiving philosophy, that is a fundamental attitude about what in life is valuable. A proponent of such classical philosophy, Pierre Hadot, writing on his own philosophical position contends that "there are universal and fundamental attitudes of the human being, when he searches for wisdom" (Hadot, 2020, p. 41). For Hadot, these attitudes are independent of the schools of thought which are said define them - for instance, for Hadot, there is a universal Epicureanism which as an attitude to life might differ from the 
specific arguments put forward by Epicureans. This attitude is found in the way of practising living, rather than theorizing. Hadot quotes Kant to elaborate on his point:

To an old man, who told him that he attended lessons on virtue, Plato responded: 'and when will you begin to live virtuously?' One cannot always theorize. One must finally aim at passing from thought to exercise. But today we take someone who lives what he teaches to be a dreamer (Hadot, 2020, p. 42).

Čapek's description of the gardener represents just such a fundamental attitude to living a virtuous life. Devoid of theory, The Gardener's Year is, however brimful of symbolic meaning on the practice of a virtuous life.

Clearly, there is far more to the depiction of gardening in Čapek's book than a mere account of a hobby. Furthermore, the description of gardening is as a character enhancing, and continuously engaging activity, rather than a peaceful, contemplative moment of reprieve from the problems of the world. For Čapek gardening is a response to the issues of the world through the germination of virtuous qualities in the people who practice it. Importantly Čapek's book is an excellent means of explaining the maxim that was hastily annunciated by the literary character of Candide a hundred and seventy-nine years previously. By exploring what the gardener does, and not just what people do in gardens, Čapek shows that if we take the activity seriously as a philosophical metaphor, it contains the image of a nuanced and moral response to evil, just as Candide declared. Capek shows that Candide was neither selfish, nor naïve at the conclusion of the book; instead Candide's (and Čapek's) insight is that character development and cultivation, is a robust, and effective way of guarding against the evils of the world which can occur without reason.

\section{References}

ARISTOTLE (1976): The ethics of Aristotle, trans. J. A. K. Thomson. Harmondsworth: Penguin Books.

BROADIE, S. (2019): Aristotle on luck, happiness, and Solon's Dictum. In: I. Church \& R. Hartman (eds.): The Routledge handbook of the philosophy and psychology of luck. London: Routledge, pp. 25-33.

ČAPEK, K. (1984): The Gardener's Year, trans. M. \& R. Weatherall. Madison WI: The University of Wisconsin Press.

COOPER, D. (2006): A philosophy of gardens. Oxford: Clarendon Press.

CRAVENS, C. (2007): Reviewed work: The Gardener's Year by Karel Čapek and Geoffrey Newsome. In: The Slavic and East European Journal, 51(1), pp. 176-177.

CROCKER, L. \& WOLPER, R. (1971): Professor Wolper's interpretation of Candide. In: Eighteenth-Century Studies, 5(1), pp. 145-156.

CULLHED, A. (2010): The garden against history; Reflections on the Hortus Conclusus theme in premodern literature. In: Bulletinin, 23, pp. 6-8.

DINAN, M. (2017): The Robot Condition: Karel Čapek's R.U.R. and Hannah Arendt on labor, technology and innovation. In: Perspectives on Political Science, 46(2), pp. 108-117.

HADOT, P. (2020): The selected writings of Pierre Hadot: Philosophy as practice, trans. M. Sharpe \& F. Testa. London: Bloomsbury.

HAMAN, A. \& TRENSKY, P. (1967): Man against the absolute: The Art of Karel Čapek. In: The Slavic and East European Journal, 11(2), pp. 168-184.

HILL, B. (2009): Introduction to the modern library gardening series. [online] [Retrieved September 22, 2020] Available at: https://davesgarden.com/guides/articles/view/2289

HIRVONEN, A. (2014): Voltaire's garden. In: Pólemos, 8(2), pp. 223-234. 
RUSHDIE, S. (2002): How Politics Took a Leaf from Voltaire's Garden. In The Guardian. Saturday April 27. [online] [Retrieved September 22, 2020] Available at: https://www.theguardian.com/books/2002/apr/27/francoismariearouetdevoltaire.salmanrushdi e

SHARPE, M. (2015): Camus, Philosophe: To return to our beginnings. Leiden: Brill.

STEWART, P. (2009): Candide. In: N. Cronk (ed.): The Cambridge companion to Voltaire. Cambridge: Cambridge University Press, pp. 125-138.

WILLIAMS, D. (1997): Voltaire. London: Grant \& Cutler Ltd. 